\title{
Виталитетная структура Convallaria majalis L. в подзоне хвойно- широколиственных лесов Кировской области
}

\section{Vitality structure of Convallaria majalis L. in coniferous-broad leaved forests subzone of Kirov region}

\author{
Сулейманова В. Н., ${ }^{1,2}$, Егошина Т. Л. ${ }^{1,2}$, Сулейманова Э. Н. ${ }^{3}$ \\ Suleimanova V. N. ${ }^{1,2}$, Egoshina T. L. ${ }^{1,2}$, Suleimanova E. N. ${ }^{3}$ \\ ${ }^{1}$ Всероссийский научно-исследовательский институт охотничьего хозяйства и звероводства им. Б. М. Житкова, г. Киров, \\ Poccuя.E-mail:venera_su@mail.ru,etl@inbox.ru \\ ${ }^{2}$ Вятская государственная сельскохозяйственная академия, г. Kиров, Poccuя.E-mail:venera_su@mail.ru, etl@inbox.ru \\ ${ }^{3}$ Башкирский государственный медицинский университет, г. Уфа, Poccuя. E-mail: e_suleymanova@mail.ru \\ ${ }^{1}$ Professor B. M. Zhitkov Russian Research Institute of Game Management and Fur Farming, Kirov, Russia \\ ${ }^{2}$ Vyatka State Agricultural Academy, Kirov, Russia \\ ${ }^{3}$ Bashkir State Medical University Ministry of Health, Ufa, Russia
}

\begin{abstract}
Peфepam. Приводятся результаты изучения виталитетной структуры ценопопуляций Convallaria majalis в подзоне хвойно-широколиственных лесов Кировской области. Виталитетный анализ показал, что практически все ценопопуляции характеризуются как процветающие, четыре ценопопуляции - депрессивные.
\end{abstract}

Ключевые слова. Виталитетная структура, Кировская область, ландыш майский, подзона хвойношироколиственных лесов, ценопопуляция.

Summary. The results of studying the vitality structure of Convallaria majalis coenopopulations in coniferous-broad leaved forests subzone of Kirov region are presented. The analysis of vitality has revealed that coenopopulations are prosperous, and four coenopopulations are depressive.

Key words. Convallaria majalis, coenopopulation, coniferous-broad leaved forests subzone, Kirov region, vitality structure.

Изучение виталитетной структуры ценопопуляций широко используется в популяционных исследованиях. Она позволяет раскрыть соотношение в популяциях особей разного виталитета, выявляет первичные изменения в состоянии особей и популяций, наиболее чувствительна при выявлении особенностей эколого-ценотической обстановки, дает оценку особей и популяций в момент исследования (Злобин, 1989, 2009).

Ландыш майский (Convallaria majalis L) - ценное лекарственное растение, доминант травяно-кустарничкового яруса лесных фитоценозов Кировской области, содержит сердечные гликозиды и стероидные сапонины. В Кировской области C. majalis включен в Приложение 2 Красной книги в список редких и уязвимых видов растений, не внесенных в Красную книгу Кировской области, но нуждающихся на территории области в постоянном контроле и наблюдении (Красная книга, 2014).

Цель работы заключается в изучении виталитетной структуры Convallaria majalis в подзоне хвойно-широколиственных лесов Кировской области.

Сбор материала проводился в период с 1980 по 2018 гг. Исследовано 34 ценопопуляций (ЦП) C. majalis (в Советском, Уржумском, Нолинском, Вятско-Полянском, Лебяжском, Кильмезском районах) в подзоне хвойно-широколиственных лесов Кировской области. Для анализа виталитетной структуры C. majalis исследовано 18 ценопопуляций. 
Описания исследованных растительных сообществ с C. majalis проводили согласно общепринятым геоботаническим методам (Методы изучения ..., 2002; Миркин, Наумова, 1998), с подробной характеристикой видового состава и физико-географических условий. Для сравнения растительных сообществ по флористическому составу использовали коэффициент сходства П. Жаккара (Методы изучения ..., 2002).

Для анализа виталитетной структуры ценопопуляций применяли методику предложенную Ю. А. Злобиным (1989), где выделяется три типа ценопопуляций, соответствующие следующим условиям: $\mathrm{Q}=1 / 2(\mathrm{a}+\mathrm{b})>\mathrm{c}$ - процветающие ценопопуляции; $\mathrm{Q}=1 / 2(\mathrm{a}+\mathrm{b})=\mathrm{c}$ - равновесные ценопопуляции; $\mathrm{Q}$ $=1 / 2(\mathrm{a}+\mathrm{b})<\mathrm{c}-$ депрессивные ценопопуляции. По показателю виталитета, особи разбиты на 3 класса: $\mathrm{a}-$ (высокий виталитет), $\mathrm{b}$ - (средний) и с - (низкий).

Ценопопуляции (ЦП) C. majalis изучены в следующих сообществах: № 1 - дубняк ландышевый, № 2 - злаково-ландышевые луга, № 3 - вырубка разнотравно-вейниковая из-под осинника, № 4 - сосняк ландышево-земляничный, № 5 - сосняк ландышево-вейниковый, № 6 - березняк с примесью сосны черничный, № 7 - сосняк с примесью березы ландышевый, № 8 - вырубка из-под березняка костянично-вейниковая, № 9 - дубняк разнотравно-ландышевый, № 10 - сосняк разнотравный, № 11 - дубняк разнотравный, № 12 - заливные разнотравные луга, № 13 - заливные разнотравные луга (островная), № 14 - сосняк с примесью березы ландышевый, № 15 - вырубка из-под сосняка кипрейно-вейниковая, № 16 - сосняк разнотравный, № 17 - дубняк пойменно-разнотравный, № 18 - сосняк с примесью березы и дуба ландышево-разнотравный, № 19 - дубняк пойменный ландышево-травяный, № 20 - сосняк травяный, № 21 - осинник снытево-ландышевый, № 22 - вырубка из-под сосняка разнотравно-ландышевая, № 23 - сосняк костянично-ландышевый, № 24 - сосняк с примесью березы травяный, № 25 - сосняк ландышевый, № 26 - заросли шиповника по краю заливного разнотравного луга, № 27 - дубняк травяный пойменный, № 28 - сосняк травяный, № 29 - дубняк травяный пойменный, № 30 - сосняк ландышевый, № 31 - открытая поляна в пихтарнике травяно-ландышевом, № 32 - пихтарник травяно-ландышевый, № 33 - осинник с примесью дуба пойменный разнотравно-орляково-костяничный, № 34 - осинник ландышево-травяный.

Изученные ЦП C. majalis приурочены к мезофильным широколиственным смешанным лесам и бореальным хвойным, относящимся к классам Querco-Fagetea Br. -Bl. et Vlieger in Vlieger 1937 и Vaccinio-Piceetea Br.-Bl. in Br.-B1., Siss. et Vlieger 1939 (Сулейманова, Егошина, 2014, 2018).

Виталитетом растений называется их жизненное состояние, оцениваемое на основании учета особенностей формы и роста растений. Он является морфоструктурным выражением жизненного состояния растений (Злобин, 2009). Характеристики жизненности и виталитетного типа ЦП C. majalis приведены в таблице.

При оценке виталитетного типа ЦП с использованием критерия Q выявлено, что почти все ЦП C. majalis характеризуются как процветающие. В четырех ЦП (2,3,7 и 15) отмечено преобладание особей низшего класса. Эти ЦП отнесены к категории депрессивных. Показатели качества ЦП низкие и варьируют от 1,67 до $35 \%$.

Среди всех депрессивных ЦП C. majalis в наихудшем положении находится ЦП 2, где отсутствуют особи высшего класса и ЦП в основном представлена особями низшего класса - 96,67 \%. Среди депрессивных ЦП одинаковые показатели имеют ЦП 3 и 15, в которых особи со средним и низшим классом составляют 40 и $60 \%$, соответственно.

Среди всех процветающих ЦП C.majalis в наилучшем положении находится ЦП 9 и 14. Здесь отмечено преобладание особей высшего класса (до 76,67 \%) и максимальные показатели индекса качества ЦП (до 88,33). Среди процветающих ЦП в наихудшем положении находится ЦП 18, которая характеризуется полным отсутствием особей высшего класса и значительной долей особей среднего класса (до $70 \%$ ).

Представленность особей разной жизненности в ЦП C. majalis следующая: в большей степени в ЦП встречаются особи среднего класса от 23,33 до 80,0 \%. Исключением является ЦП 2, в которой эти особи составляют лишь $3,33 \%$ от общего числа особей. Особи среднего класса составляют - 50,01\%. Значительно реже встречаются особи низшего класса от 6.67 до 50 \%. В ЦП 7 эти особи отсутствуют. В меньшей степени встречаются особи с высокой жизненностью от 1,82 до 46,67 \%. Исключением является ЦП 7, в которой выявлено максимальное количество особей - до 90,41 \% от общего числа особей. 
Характеристики жизненности и виталитетного типа ценопопуляции Convallaria majalis

\begin{tabular}{|c|c|c|c|c|c|}
\hline \multirow{2}{*}{ № ценопопуляции } & \multicolumn{3}{|c|}{ Доля особей по классам виталитета, \% } & \multirow{2}{*}{$\begin{array}{c}\text { Качество } \\
\text { ценопопуляции (Q) }\end{array}$} & \multirow{2}{*}{$\begin{array}{c}\text { Виталитетный тип } \\
\text { ценопопуляции }\end{array}$} \\
\hline & Крупные, а & Средние, b & Мелкие, с & & \\
\hline 1 & 6,67 & 66,67 & 26,67 & 40,0 & Процветающая \\
\hline 2 & 0 & 3,33 & 96,67 & 1,67 & Депрессивная \\
\hline 3 & 0 & 40,0 & 60,0 & 20,0 & Депрессивная \\
\hline 4 & 40,0 & 43,33 & 16,67 & 61,67 & Процветающая \\
\hline 5 & 36,67 & 56,67 & 6,67 & 65,0 & Процветающая \\
\hline 6 & 0 & 76,67 & 23,33 & 38,33 & Процветающая \\
\hline 7 & 10,0 & 50,0 & 40,0 & 35,0 & Депрессивная \\
\hline 8 & 18,52 & 48,15 & 33,33 & 42,59 & Процветающая \\
\hline 9 & 50,0 & 45,45 & 4,55 & 72,73 & Процветающая \\
\hline 10 & 13,33 & 80,0 & 6,67 & 53,33 & Процветающая \\
\hline 11 & 76,67 & 23,33 & 0 & 88,33 & Процветающая \\
\hline 12 & 3,33 & 70,0 & 26,67 & 38,33 & Процветающая \\
\hline 13 & 20,0 & 63,33 & 16,67 & 51,67 & Процветающая \\
\hline 14 & 76,67 & 23,33 & 0 & 88,33 & Процветающая \\
\hline 15 & 0 & 40,0 & 60,0 & 20,0 & Депрессивная \\
\hline 16 & 13,33 & 63,33 & 23,33 & 45,0 & Процветающая \\
\hline 17 & 50,0 & 36,67 & 13,33 & 68,33 & Процветающая \\
\hline 18 & 0 & 70,0 & 30,0 & 35,0 & Процветающая \\
\hline
\end{tabular}

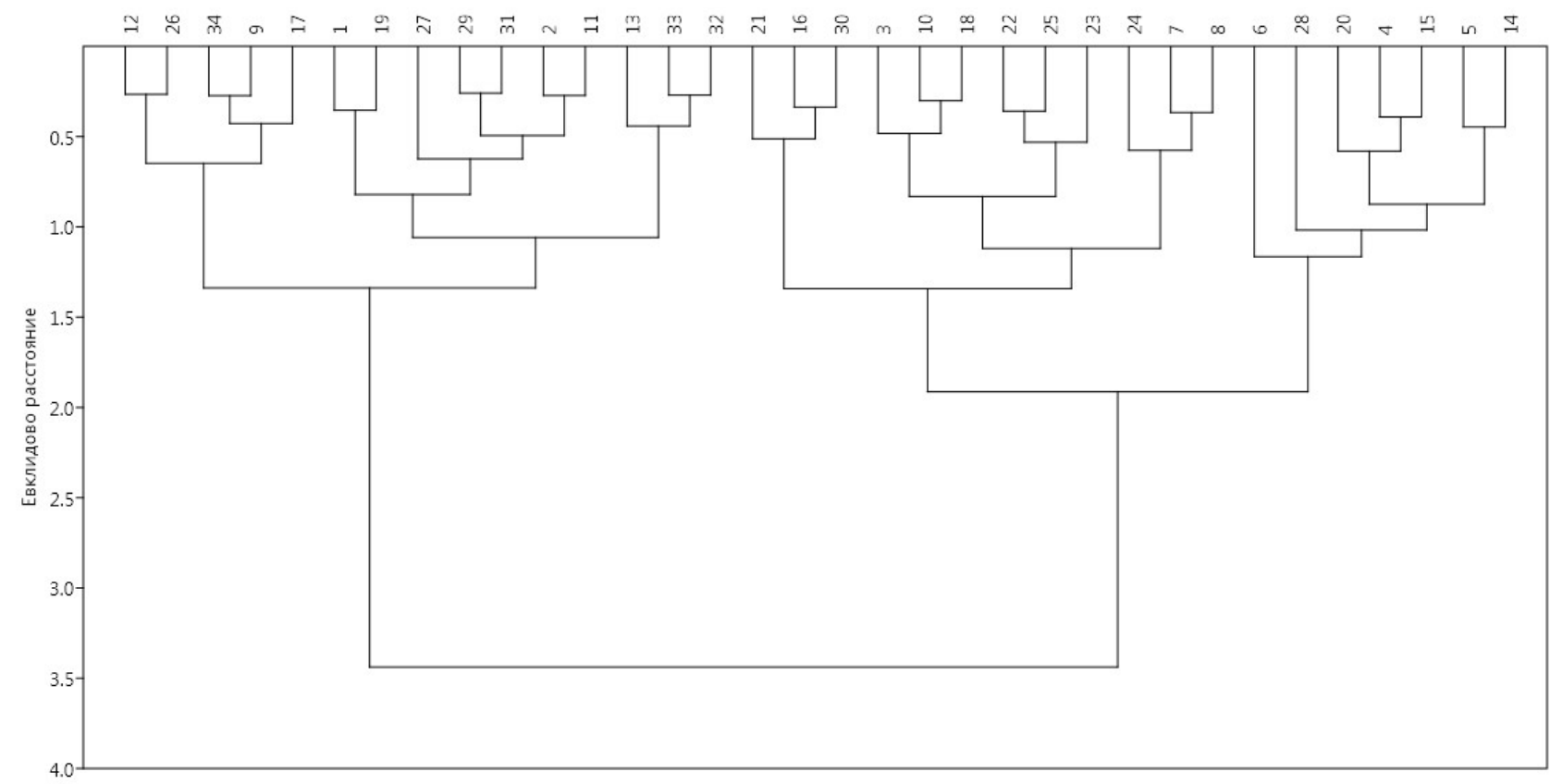

Рис. Дендрограмма сходства по видовому составу сообществ с Convallaria majalis. По горизонтали - номер ценопопуляции, по вертикали - межкластерное расстояние.

Кластерный анализ видового разнообразия сообществ с C. majalis по коэффициенту общности П. Жаккара показал разделение ЦП на два кластера (рис.). Первый кластер подразделяется на два субкластера, один из которых сформирован ЦП 12, 26, 9, 17 а второй субкластер образуют ЦП 1, 19, 27, 29, $2,11,13$. Это в основном луговые сообщества и дубняки. С меньшей долей вероятности к ним примыкают ЦП C. majalis изученные в осинниках и пихтарниках (ЦП 31-34). Во второй кластер также четко 
входят два субкластера и объединяют ЦП C. majalis произрастающих в сосняках (ЦП 4-7, 10, 14, 16, 18 , $20,23-25,28,30$ ) и на вырубках (ЦП $3,8,15,22)$.

Таким образом, все ЦП C. majalis характеризуются как процветающие. Исключением являются четыре ЦП, характеризующиеся как депрессивные с высокой долей особей низшего класса.

Представленность особей разной жизненности в ЦП следующая: в большей степени в ЦП встречаются особи со средней жизненностью (50,01\%). Реже встречаются особи с низкой жизненностью (26,92 \%). В меньшей степени встречаются особи с высокой жизненностью $(23,07$ \%).

На дендрограмме сходства (рис.) наблюдается разделение ЦП C. majalis на два кластера. Первый кластер включает разнотравные луга и дубняки, второй кластер - сосняки и вырубки.

\section{ЛИТЕРАТУРА}

Злобин Ю. А. Принципы и методы изучения ценотических популяций растений. - Казань: Изд-во Казан. унта, 1989. $-146 \mathrm{c}$.

Злобин Ю. А. Популяционная экология растений: современное состояние, точки рост: монография. - Сумы: Университетская книга, 2009. - 263 с.

Миркин Б. М., Наумова Л. Г. Наука о растительности (история и состояние основных концепций). -Уфа: Гилем, 1998. $-413 \mathrm{c}$.

Методы изучения лесных сообществ. - СПб.: НИИХимии СПбГУ, 2002. - 240 с.

Красная книга Кировской области. - Киров, 2014. - 336 с.

Сулейманова В. Н., Егошина Т. Л. Эколого-фитоценотическая характеристика Convallaria majalis L. в подзоне хвойно-широколиственных лесов Кировской области // Вестник Удмуртского государственного университета, 2014. - Вып. 1. - С. 49-56.

Сулейманова В. Н. Егошина Т. Л. Анализ изменчивости морфологических признаков Convallaria majalis L. в Кировской области // Международная научная конференция «Перспективы лекарственного растениеведения»: Сб. науч. трудов. - М.: ВИЛАР, 2018. - С. 52-57. 